sidered probable that if vaccination were to be abandoned there would be a return within a few years to the former high prevalence and severity of infections.

The pertussis vaccines in use today are not the same as those used to immunize the children observed in the survey. Since 1964 all manufacturers in Britain have included strains of type 1,3 in their vaccines, and continuing efforts have been made to increase the protective effectiveness of the vaccines without increasing their toxicity. ${ }^{7}$ It seems important that the efficacy of the improved vaccines should be assessed in further surveys and trials before any final decision is taken about the place of pertussis vaccination in the immunization programme. The Public Health Laboratory Service has shown itself well fitted to make such surveys, and it is to be hoped that it will undertake the valuable function of keeping under surveillance the efficacy of the pertussis and other vaccines now in general use.

\section{Society's Rejects}

During the past two or three years the image of our mental hospitals, including those for the mentally subnormal, has taken a terrible battering. It is true that some of the blows misfired-as, for example, that dealt by Sans Everything ${ }^{1}-$ but others, like the Ely report ${ }^{2}$ and the Farleigh Hospital inquest ${ }^{3}$ into the death of two patients, have landed fair and square on the chin.

The recently published book by Pauline Morris, ${ }^{4}$ despite its unfortunate title and the publicity it received, is neither a piece of sensational journalism nor an account of an inquisition. It is a piece of first-class social research beautifully designed and splendidly executed. It was carried out by skilled sociologists with no preconceived notions and no clinical or medico-political axes to grind. Despite the sophistication of the techniques employed the report is eminently readable and easily comprehensible. The team of research workers headed by Dr. Morris began their inquiry in 1964-that is, before Ely -and the book's publication at this moment of crisis appears to be fortuitous.

The team visited nearly half the hospitals for the subnormal in the country (some 34 ) together with a number of voluntary hospitals and homes. To supplement this national sample. two hospitals, polar opposites in almost every context, were studied more intensively. The aims of the survey are precisely stated : "To discover what facilities-physical, occupational and educational-there were for patients [in hospitals for the subnormal]" ; and, "to learn something of the relationship between the hospital as an institution and the outside community, as well as between the patients and the outside world." In an inquiry as widespread as this no universal truths emerge. Hospitals vary in quality between themselves and indeed between their component parts.

Nevertheless the picture is, by and large, depressing to say the least, as depressing as the sketch drawn in a leading article in this journal ${ }^{5}$ which raised the hackles of some of its readers. Dr. Morris talks, for example, of " overcrowding and the con1 Sans Everything : A Case to Answer, presented by Barbara Robb, 1967.

British Medical fournal, 1969, 2, 6

3 British Medical Fournal, 1969, 3, 481

Morris, P., Put Away: A Sociological Study of Institutions for the Mentally Retarded, 1969. London, Routledge and Kegan Paul. (60s.

British Medical fournal, 1969, 3, 426. sequential effects on staff and patients" ; of the appalling smell of the sanitary annexes ; of the severely disturbed behaviour of some of the patients; of the incidence of incontinence (" 50.5 per cent. of the 362 children are severely incontinent"). She tells of the acute shortage of staff, particularly domestic, and of their low morale ; of the difficulty of employing immigrants- " The patients don't understand them and they get upset," said one of the nurses interviewed. She mentions the prevalence of homosexual practices, unavoidable in the circumstances. There is an account of fifty older children wandering round the ward aimlessly or sitting making noises.

Nor does the medical profession escape censure. Doctors are on record as having drifted into the work with subnormals and of having accepted that the specialty is a medical backwater : "Third-class doctors in a third-class service," as a deputy superintendent of one of these hospitals put it in a recent television programme. It could be added parenthetically that despite this self-denigration some of the most important advances in psychiatry are due to workers in the field of subnormality-for example, in the study of biochemical and chromosomal defects.

The employment, or lack of it, of the patients is discussed ; " the great majority spend their day sitting interspersed with eating." The shortage of paramedical workers and the misemployment of some of those available is underlined. What is particularly disconcerting is the use of tranquillizing drugs not for their therapeutic but for their custodial effect. This gives credence to the oft-quoted gibe that the physical straitjackets of yesterday have given way to the chemical straitjackets of today.

It is important to note that Dr. Morris throughout the book refrains from passing judgements or assuming a selfrighteous attitude. She is deeply aware of the gravity of the problem she has exposed. In the end it can be solved only by the very people who are all too busy throwing punches at those attempting to cope with it. This is explicit in her final sentence, "The staff in the subnormality hospitals badly need better instruction and guidance, as well as more time to devote to fewer patients, but it should not be forgotten that in one important sense many of them accept those whom society chooses to reject."

\section{Genetics and Infection}

The outcome of an infection depends on the virulence of the invading organism and the resistance of the host. The host's resistance has three major components. These are, firstly, innate immunity, which is to a large extent under genetic control ; secondly, acquired immunity, which involves reactions of immunocompetent cells, such as the synthesis of different classes of antibody and the development of cellmediated immunity; and, thirdly, the physiological state of the host, including such factors as age, nutritional status, stress, and hormonal influences.

Observations on patients and experimental animals gathered during the last few years show the interaction of all these factors in host resistance. The importance of acquired immunity is illustrated by the well-known susceptibility to infections of patients with immune-deficiency syndromes or receiving immunosuppressive therapy. ${ }^{12}$ There is some specificity in these effects. Thus, children with agamma- 
globulinaemia tend to develop recurrent infections with extracellular pyogenic pathogens ; some children with selective IgA deficiency have bronchitis, sinusitis and exudative enteropathy ; and those with defective cell-mediated immune responses often die of fungal or viral infections in early childhood.

Some inherited defects predisposing patients to infection involve leucocytes and not, directly, immunocompetent cells. In 1957 attention was drawn to a syndrome in male children which has been termed fatal granulomatous disease of childhood. ${ }^{3}$ The characteristic features ${ }^{4}$ are recurrent suppurative lymphadenopathy, pulmonary granulomatous infiltration, and visceral abscesses, often accompanied by anaemia, leucocytosis, and increased serum immunoglobulins. The polymorphonuclear leucocytes and monocytes of these patients fail to destroy ingested bacteria or viruses efficiently. ${ }^{4-6}$ This accounts for the production of chronic granulomatous disease by bacteria and fungi, including some of low pathogenicity in healthy persons. The leucocytes of affected patients show deficient DPNH oxidase activity after ingestion of particles. ${ }^{78}$ It has been reported that biochemical tests also show diminished DPNH oxidase activity in the leucocytes of the patients, ${ }^{9}$ though it is still uncertain whether this observation is reproducible and whether it represents a primary or a secondary change. The mode of inheritance of the disease is uncertain. Some evidence suggested that it is inherited as an X-linked character, ${ }^{10}$ but some reports indicate an autosomal recessive condition the expression of which varies in the two sexes. ${ }^{11}$ Possibly it is sex-linked in some families but autosomal in others. Thus much remains to be learned about chronic granulomatous disease, but it is established that here is an inherited defect in the capacity of leucocytes to kill invading organisms, which greatly lowers the host's resistance to infection.

The Chediak-Higashi syndrome was recognized because of the presence of unusually large granules (lysosomes) in leucocytes. ${ }^{12-14}$ It is also associated with a pale colour of skin, hair, and eyes, which has been attributed to the presence of large pigment granules that do not absorb light efficiently. ${ }^{15}$ Thus the basic defect may be in the structure of the membranes surrounding cytoplasmic organelles, which are either synthesized large or fuse with one another to form giant granules. The condition is inherited as an autosomal recessive, and affected children show an increased susceptibility to infections such as pneumonia, oral ulceration, and pyoderma. At some time, ranging from a few months of age to adolescence, these children tend to develop a severe

1 Bergsma, D., ed., Immunologic Deficiency Diseases in Man, 1968, National Foundation-March of Dimes.

2 Soothill, J. F., in Clinical Aspects of Immunology, 2nd ed., p. 540 ed. P. H. G. Gell and. R. R. A. Coombs, 1968. Oxford, Blackwcl Scientific Publications.

s Berendes, H., Bridges, R. A., and Good, R. A., Minnesota Medicine, $1957,40,309$

- Holmes, B., Quie, P. G., Windhorst, D. B., and Good, R. A., Lancet,

1966, 1, 1225.

1967, 1, 408. Davis, W. C., Douglas, S. D., and Fudenberg, H. H., Annals of Internal Medicine, 1968, 69, 1237.

- Baehner, R. L., and Nathan, D. G., Science, 1967, 155, 835

Baehner, R. L., and Nathan, D. G., New England fournal of Medicine, 1968, 278, 971 .

- Baehner, R. L., and Karnovsky, M. L., Science, 1968, 162, 1277.

10 Windhorst, D. B., Holmes, B., and Good, R. A., Lancet, 1967, 1, 737. Chandra, R. K., Cope, W. A., and Soothill, J. F., Lancet, 1969, 2, 71 .

12 Béguez César, A., Boletin de la Sociedad Cubana de Pediatria, 1943,

$15,900$.
1s Steinbrinck, W., Deutsches Archiv fur klinische Medizin, 1948, 193, 577.

${ }_{14}$ Chediak, M., Revue d'Hématologie, 1952, 7, 362.

is Windhorst, D. B., Zelickson, A. S., and Good, R. A., Science, 1966, 151,81 . lymphoma-like illness which is often rapidly fatal. ${ }^{16}$ There is evidence of defective granulopoiesis, with intramedullary destruction of granulocytes. A similar anomaly is known in mink. ${ }^{18} 19$

A third condition is absence of the enzyme myeloperoxidase in polymorphonuclear leucocytes and monocytes, but not eosinophils. This has been described in a 48-year-old man with disseminated candidiasis. ${ }^{20}$ The leucocytes showed deficient capacity to kill ingested Candida albicans and some bacteria. This is of interest, incidentally, in relation to investigations suggesting that hydrogen peroxide, in the presence of myeloperoxidase and a suitable oxidizable substrate such as halide, can form an efficient bactericidal system. ${ }^{21}$ However, this patient was obviously much less susceptible to bacterial infection than are patients with chronic granulomatous disease, which suggests that killing mechanisms other than those involving peroxidase can be highly effective in leucocytes.

Several examples of inherited factors conferring resistance against infection have been studied in detail. There is much evidence that children heterozygous for the sickle-cell trait are resistant to malignant tertian malaria, ${ }^{22}$ and recently further evidence has been presented that this is also true of glucose-6-phosphate dehydrogenase deficiency. Females heterozygous for this enzyme deficiency are mosaics having two populations of red cells, one with normal enzyme levels, the other with low enzyme levels. The two populations can be distinguished histochemically, and L. Luzzatto and his colleagues $^{23}$ found that Plasmodium falciparum parasites were much less frequently present in the enzyme-deficient cells than in the normal cells. The malaria parasites grow better in erythrocytes with normal G.6P.D. levels than in cells with deficient enzyme levels. Selection through resistance to malaria could account for the high frequencies of sickling and G.6P.D. deficiency in many populations living in regions where malaria has been endemic. ${ }^{22}$

Several examples of single major genetic factors in mice which confer resistance against virus infections have been described, ${ }^{24-27}$ and there is good evidence that blood groups influence susceptibility to virus infections in man. A study of servicemen admitted to sick quarters with acute respiratory infections during 1956-61 showed that infection by the recently arrived Asian strain of A2 influenza virus was commoner in persons of blood group $\mathrm{O}$ than in persons of blood group $\mathrm{A}^{28}$ And antibody to A2 influenza virus has been found in a higher proportion of sera from civilians of blood group $\mathrm{O}$ than from age-matched persons of blood group $\mathbf{A}^{28}$ Later it was found that this difference had disappeared, prob-

I6 Dent, P. B., Fish, L. A., White, J. G., and Good, R. A., Laboratory Investigation, 1966, 15, 1634.

17 Blume, R. S., Bennett, J. M., Yankee, R. A., and Wolf, S. M., New England Fournal of Medicine, 1968, 279, 1009.

18 Henson, J. B., Gorham, J. R., and Leader, R. W., Texas Reports on Biology and Medicine, 1963, 21, 37.

19 Porter, D. D., Dixon, F. J., and Larsen, A. E., Blood, 1965, 25, 736 20 Lehrer, R. I., Hanifin, J,. and Cline, M. J., Nature, 1969, 223, 78.

21 Klebanoff, S.' J., Fournal of Experimental Medicine, 1967, 126, 1063

22 Allison, A. C., Cold Spring Harbor Symposia on Quantitative Biology, 1964, 29, 137.

${ }_{23}$ Luzzatto, L., Usanga, E. A., and Reddy, S., Science, 1969, 164, 839.

24 Allison, A. C., Archiv für die gesamte Virusforschung, 1965, 17, 280. Bang, F. B., and Warwick, A., Proceedings of the National Academy of Sciences of the United States of America, 1960, 46, 1065

26 Goodman, G. T. and Koprowski, H., Fournal of Cellular and Comparative Physiology, 1962, 59, 333 .

parative Physiology, 1962, 59, 333.
Mims, C. A., Bacteriological Reviews, 1964, 28, 30.

27 Mims, C. A., Bacteriological Reviews, 1964, 28, 30. McDonal

2, 89. C. W., and Schild, G. C., Fournal of Immunology, 1967, 98,
Potter, C.

${ }^{30}$ Potter, C. W., fournal of Hygiene, 1969, 67, 67.

31 Tyrrell, D. A. J., Sparrow, P., and Beare, A. S., Nature, 1968, 220, 819. 
ably owing to reinfection of persons with group A. ${ }^{28}$ Likewise, serological evidence shows that young persons of group $O$ are more often infected with adenoviruses type 3 and 7 than those of group A, but in older people the difference disappears. ${ }^{30}$ Hence repeated exposure of a population obscures genetically determined variations in susceptibility. In studies of volunteers exposed to influenza virus a significantly higher percentage of persons with blood group $\mathrm{O}$ than those with blood group A became infected. ${ }^{31}$

Thus there is substantial evidence that susceptibility to infection is under genetic control and that this has many different aspects. They include destruction of invading rganisms by leucocytes, acquired immune responses, and other constritutional factors, most of which are not yet analysed. This is relevant not only to resistance against infection but also the maintenance of genetic diversity in populations.

\section{Mental Problems in Rheumatoid Arthritis}

An important principle in medicine is to treat the sick person and not just his illness. This applies particularly to patients with chronic disability. Patients with severe rheumatoid arthritis are afflicted by a continuing disease process, which is often a worsening one. That there are important effects on the psyche is not surprising when it is considered that the disability is compounded by pain, stiffness, limitation of movement, anaemia, and generalized constitutional upset. Further problems arise as mobility decreases. There is loss of time from work, even loss of livelihood, inability to do housework, and increasing restriction of leisure activities. Personal relationships may become strained, adding to the already considerable domestic and social difficulties. In this situation patients with rheumatoid arthritis often show feelings of resentment and contained hostility. ${ }^{1-3}$ However, these features are not peculiar to this type of disability and there are many patients with the disease who do not show these traits.

Psychogenic factors are also of importance in causing deterioration in patients who were previously coping well with their disability. An emotional upset can precipitate an exacerbation of the disease, whether it is due to the death or departure from home of a close relative, the infidelity of a spouse, or the waywardness of an adolescent child. Though the disease appears to worsen objectively in many cases, in others the deterioration is merely due to increased awareness of joint symptoms, with inhibitory effects on movement leading to increased muscle wasting and joint deformity. Occasionally the impression is gained of strong continuing psychological influences on the course of the disease. Some patients present with loss of movement which is not in keeping with the degree of disease activity present. Radiographs show

1 Mueller, A. D., and Lefkovits, A. M., fournal of Clinical Psychology, 1956, 12, 143.

- Cormier, B. M., and Wittkower, E. D., Canadian Medical Association Fournal, 1957, 77, 533

- Cobb, S., Arthritis and Rheumatism, 1959, 2, 419.

- Eysenck, H. J., The Maudsley Personality Inventory, 1959. London, University of London Press.

- Foulds, G. A., Personality and Personal Illness, 1965. London, Tavistock Publications. considerable osteoporosis but few joint erosions. In contrast, others maintain good movement, appear to disregard their symptoms almost totally, and in this way abuse their joints so that gross destructive changes occur.

The importance of treating the individual as well as his arthritis becomes readily apparent in these circumstances. Admission to hospital offers the best opportunity for teaching the patient how to live with his disease. The institution of measures to reduce disease activity, to correct deformity, and to restore muscle function is in itself good psychotherapy, particularly if it is accompanied by an optimistic attitude on the part of the medical and nursing staff. Patients should be given a thorough explanation of the aims in view and how to maintain their improvement when they return home. Often there are psycho-social problems which need attention. Continuing anxiety and depression may impede progress. An interview by the medical social worker may disclose previously concealed domestic or vocational problems. The physician himself should consider it his responsibility to interview patients in whom deep-seated psychological problems are suspected. He might preface his questioning with the assurance that mental stresses or emotional problems can have physical consequences. Specifically designed questionaries are valuable to the doctor who is not trained in psychiatry. These ask a variety of questions referring to recognized symptoms of anxiety, depression, and character features such as aggression. The inventories devised by H. J. Eysenck ${ }^{4}$ and G. A. Foulds ${ }^{5}$ are suitable for the patient with rheumatoid arthritis provided that symptoms attributable to the disease process are not scored. Often the patient is induced to talk more freely about his problems when he appreciates the direction which the interview is taking and the helpful attitude of the interviewer.

Overt states of depression and tension can arise in patients with rheumatoid arthritis which require the assistance of the psychiatrist. In these patients the psychiatric condition requires urgent treatment, otherwise treatment of the arthritis will be unsuccessful. But even in less obvious cases the importance of psychological factors in influencing the course of rheumatoid arthritis needs to be appreciated. If they are ignored the patient may deteriorate rapidly on leaving the hospital environment.

\section{Rectal Examination and the Heart}

Part of the folklore of medicine is the belief that rectal examination is potentially dangerous in patients with myocardial infarction and should be postponed until the acute episode has passed. In practice this usually means that it is carried out only if there are definite indications.

D. L. Earnest and G. F. Fletcher ${ }^{1}$ have now shown that this view cannot be supported by factual evidence, and indeed the advantages of rectal examination may outweigh any

\footnotetext{
Earnest, D. L., and Fletcher, G. F., New England fournal of Medicine, $1969,281,238$

2 Katz, D., and Selesnick, S., Gastroenterology, 1957, 33, 650.

s Palmer, E. D., and Wirts, C. W., Fournal of the American Medical Association, 1957, 164, 2012.

- Fletcher, G. F., Earnest, D. L., Shuford, W. F., and Wenger, N. K., Archives of Internal Medicine, 1968, 122, 483

s Crittenden, P. J., and Ivy, A. C., American Heart fournal, 1933, 8, 